\title{
In-vivo and in-vitro maturation rate of oocytes from two strains of mice
}

\author{
Z. Polański \\ Department of Genetics and Evolution, Institute of Zoology, Jagiellonian University, Karasia 6, \\ 30-060 Kraków, Poland
}

\begin{abstract}
Summary. Female mice of the KE and CBA strains were used to examine the rate of oocyte maturation in vivo and in vitro. In CBA females killed just before ovulation most preovulatory oocytes were already in the metaphase II stage, while the oocytes of KE mice were arrested at metaphase I until the time of ovulation, and further stages of maturation occurred in the oviduct, reaching the metaphase II stage 3-5 h later. A similar strain difference in oocyte maturation rate was observed from in-vitro culture of cumulus-free oocytes, isolated from the ovaries of PMSG-primed females and intact females killed at the metoestrous phase of the cycle. This indicates that the strainspecific course of maturation is determined in the oocyte by a few days before ovulation. Therefore, if the rate of oocyte maturation is influenced by somatic components of the follicle, this must occur at some earlier stages of follicle development.
\end{abstract}

\section{Introduction}

Mouse oocytes enter prophase of meiosis at the end of fetal life and become arrested in late prophase of the first meiotic division, i.e. in the dictyate (germinal vesicle, GV) stage. In the mature female, in each oestrous cycle, endogenous gonadotrophins stimulate a group of Graafian follicles which eventually proceed to ovulation. A few hours before ovulation, after germinal vesicle breakdown (GVBD), the oocytes progress through metaphase I, anaphase I, telophase I with extrusion of the first polar body, to the metaphase II stage. This set of events is called oocyte maturation (Donahue, 1972). Oocytes are ovulated in the metaphase II stage (Donahue, 1972) and need penetration by the spermatozoon or parthenogenetic activation to complete meiosis.

The study of Edwards \& Gates (1959) did not reveal any differences between the two strains of mice studied ( $\mathrm{J}$ and $\mathrm{L}$ ) in the oocyte maturation rate in vivo. Oocyte maturation rate in vitro is similar to that in vivo (Edwards, 1965) but with some asynchrony as regards the time when the metaphase II is reached (Donahue, 1968).

Two inbred strains of mice used in this study, CBA/Kw (referred to hereafter as CBA) and $\mathrm{KE}$, differ greatly in several properties related to fertility: i.e. efficiency of fertilization in vivo (Krzanowska, 1970) and in vitro (Kaleta, 1977), the number of cortical granules in the oocytes (Wabik-S̀liz, 1979), the rate of cumulus oophorus dispersion (Krzanowska, 1972) and zona pellucida dissolution (Krzanowska, 1972; Kaleta \& Polak, 1978). A difference in oocyte maturation rate has also been found; just before ovulation the oocytes of KE mice are still in the metaphase I stage, while the oocytes of CBA females have started to extrude their first polar body $3 \mathrm{~h}$ earlier (Krzanowska, Lorenc, Koncewicz \& Lipina, 1984).

A block at metaphase I often occurs in mouse oocytes cultured in vitro (Donahue, 1968; Sorensen \& Wassarman, 1976). Moreover, even in vivo, in NMRI/Han strain females induced to superovulate, about $10 \%$ of oocytes remain permanently blocked at metaphase I (Hansmann \& El-Nahass, 1979; Hansmann, Jenderny \& Probeck, 1983). The first aim of the present study was therefore to investigate whether all $\mathrm{KE}$ oocytes arrested in metaphase I resume maturation. 
It has been shown that the gap junctions existing between oocyte and cumulus cells allow for reciprocal metabolic cooperation (Gilula, Epstein \& Beers, 1978) and it was suggested that this coupling plays an important role in the control of resumption of meiosis by the oocyte (Eppig, Freter, Ward-Bailey \& Schultz, 1983). Therefore, to examine whether atypical maturation of KE oocytes is influenced by their environment, it was decided to compare maturation rate of KE and CBA oocytes isolated from ovaries and cultured in vitro without follicular cells.

\section{Materials and methods}

The females used were from the CBA and KE inbred strains of mice bred in the Department of Genetics and Evolution.

In-vivo oocyte maturation. Sexually mature KE female mice were injected (regardless of the day of their cycle) with 5 i.u. PMSG (Serogonadotropin; Biowet, Poland) and 46-48 h later with 5 i.u. hCG (Pregnyl, N.V. Organon, Oss, The Netherlands). Animals were killed by cervical dislocation $12-18 \mathrm{~h}$ after the last injection, their oviducts were removed and the ampullae were dissected in physiological saline $(0.9 \%(\mathrm{w} / \mathrm{v}) \mathrm{NaCl})$ containing $0.5 \%$ bovine testicular hyaluronidase (Laboratory of Sera and Vaccines, Warsaw) to disperse the cumulus cells. Oocytes with a detached zona pellucida or with fragmented cytoplasm were discarded. In females killed 12-13 h after hCG injection, oocytes were also released from ovaries by puncturing large ovarian follicles; after dispersion of cumulus cells in hyaluronidase solution, oocytes with GVBD were used for investigations.

Oocytes from MPSG-primed females of both strains began to extrude the first polar body and checked every morning for the presence of a vaginal plug which, if present, indicated ovulation. These females were killed 3-4 h after the midpoint of the dark period of the light cycle, i.e. near the time of expected ovulation (calculated according to Braden, 1957). Their ampullary and ovarian oocytes were collected as described for hormonally treated females.

Cumulus-free oocytes obtained from the ovaries or oviducts were transferred onto slides, airdried, fixed in acetic alcohol ( 3 parts absolute ethanol, 1 part glacial acetic acid) and stained with $2 \%$ aqueous toluidine blue (Krzanowska \& Lorenc, 1983). Estimation of the stage of meiosis was based on the chromatin structure and the presence of the first polar body. From some oocytes chromosome preparations were made according to the method of Tarkowski (1966). On such preparations metaphase I and II can be clearly distinguished by chromosome configuration (Figs la \& b).

The stages of maturation of ovarian oocytes were also examined on histological preparations of ovaries from KE and CBA females killed 6-12 h after hCG injection. These preparations were made in our department for other purposes and some were used in the study of Krzanowska et al. (1984).

In-vitro oocyte maturation. Female mice from the KE and CBA strains were killed $48-51 \mathrm{~h}$ after injection of 5 i.u. PMSG or at metoestrus of the sexual cycle. Ovaries were removed and all further operations were carried out in Hepes-buffered medium M2 (Fulton \& Whittingham, 1978) under paraffin oil. Oocytes were picked out from large follicles into a medium containing $0.05 \%$ hyaluronidase and released from cumulus cells by passing through a narrow pipette. Denuded oocytes were washed twice and those with a germinal vesicle were placed in drops of medium on the culture dish (2-9 oocytes per drop). Culture was carried out in Medium M2 under paraffin oil in $37^{\circ} \mathrm{C}$. $\mathrm{CBA}$ and $\mathrm{KE}$ oocytes were cultured in separate drops on the same dish. At intervals from the start of culture (Table 2) oocytes were screened under the inverted microscope for extrusion of the first polar body.

Statistics. Significance of differences in oocyte maturation rate between both strains of mice was evaluated by the test of independence adjusted for low quantities (Snedecor, 1955). 


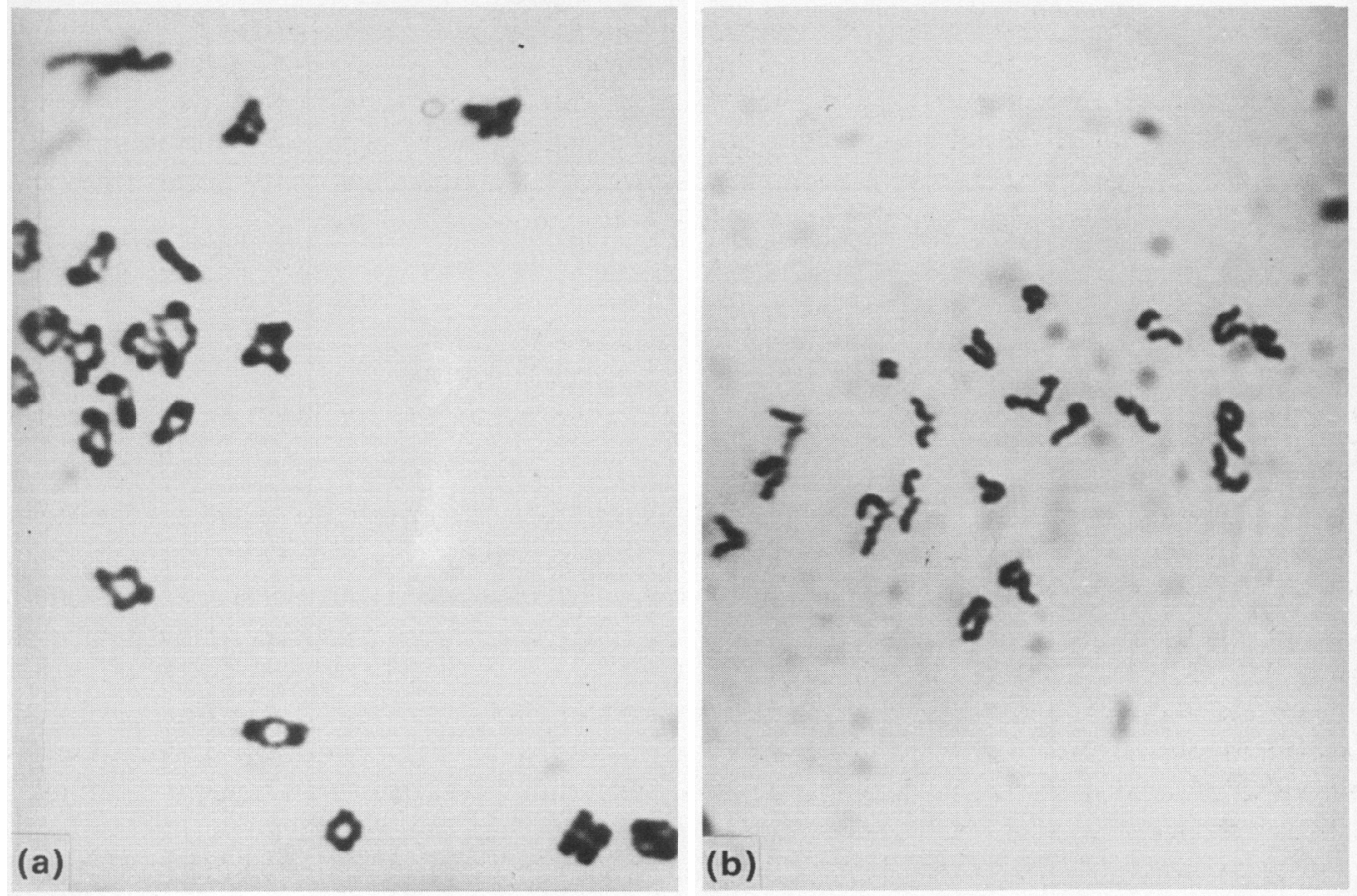

Fig. 1. Metaphase I (a) and metaphase II (b) plates of mouse oocytes with characteristic chromosome configurations.

\begin{abstract}
Results
In-vivo oocyte maturation

The stages of in-vivo maturation of oocytes from CBA and KE females are shown in Table 1. Data from the present experiments and from histological preparations are combined.

All oocytes obtained from females of both strains killed 6 and $7.5 \mathrm{~h}$ after hCG injection were in metaphase I. In those from KE mice this stage of maturation persisted in the majority of oocytes until $11 \mathrm{~h}$ after hCG, when ovulation started. At $12 \mathrm{~h}$ after hCG, 52\% of oocytes were still in metaphase I, while the rest progressed to more advanced stages. Metaphase II was first observed in some oocytes of KE females killed $14 \mathrm{~h}$ after hCG and found in all oocytes examined $18 \mathrm{~h}$ after hCG.

In CBA females, however, by $9 \mathrm{~h}$ after hCG injection only a few oocytes remained in metaphase $\mathrm{I}$, and the majority (79\%) were in telophase. By $10 \mathrm{~h}$ after hCG $49 \%$ of oocytes were already in metaphase II and no metaphase I was noted. By $12 \mathrm{~h}$ after hCG injection, when ovulation begins in this strain (Wabik-S̀liz, 1979), the proportion of metaphase II oocytes had increased to $74 \%$.

Results obtained from natural ovulations of KE females were comparable to those from superovulated ones. Amongst oocytes from females killed near the time of natural ovulation, $24 \%$ were still in metaphase I and only $10 \%$ in metaphase II.
\end{abstract}

\title{
In-vitro oocyte maturation
}

Table 2 shows the rate of the first polar body extrusion by cultured oocytes from both strains. Oocytes of CBA females killed at metoestrus began to extrude the first polar body between 8 and $9 \mathrm{~h}$ of culture. In the same conditions first polar bodies in KE oocytes appeared between 16 and $18 \mathrm{~h}$ of culture. 


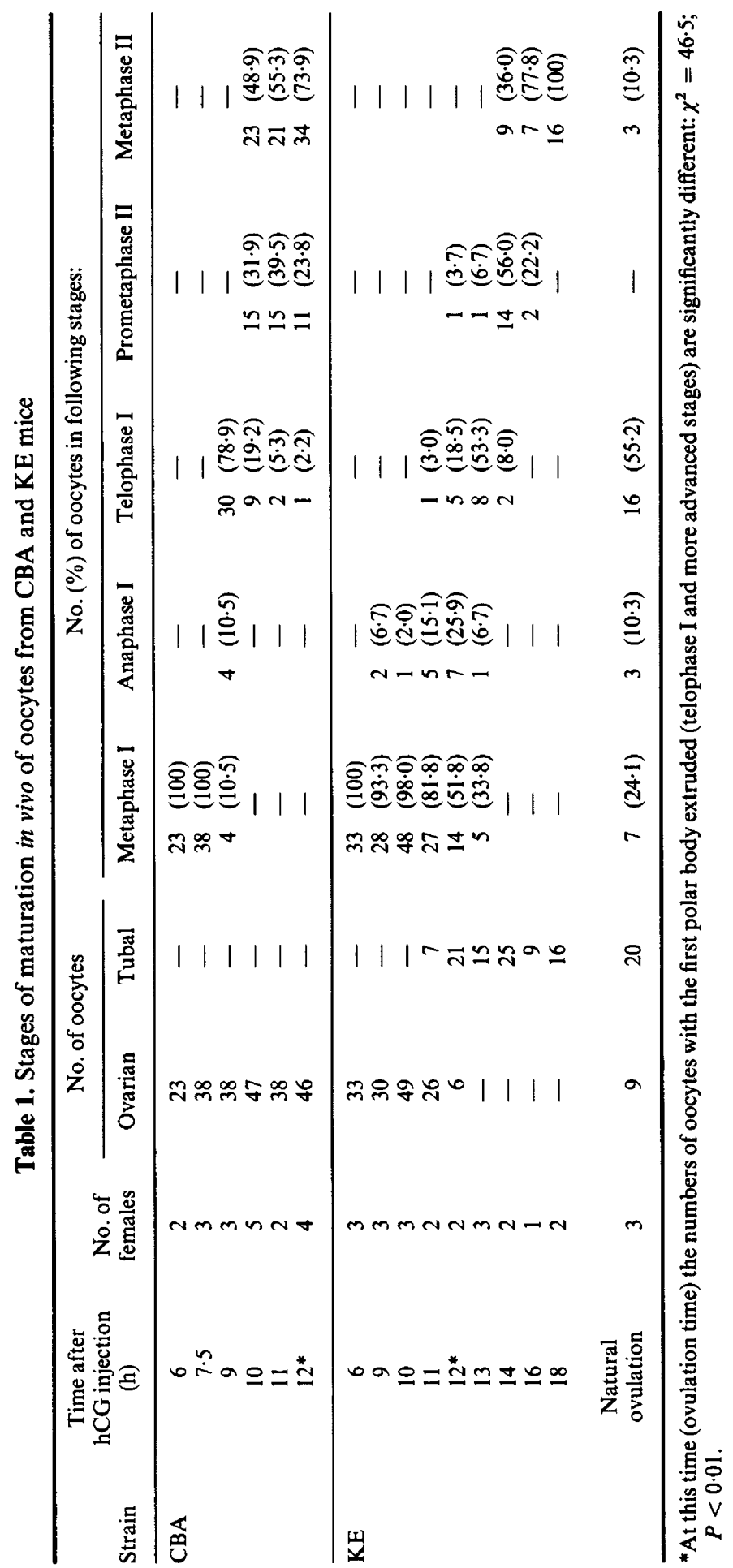




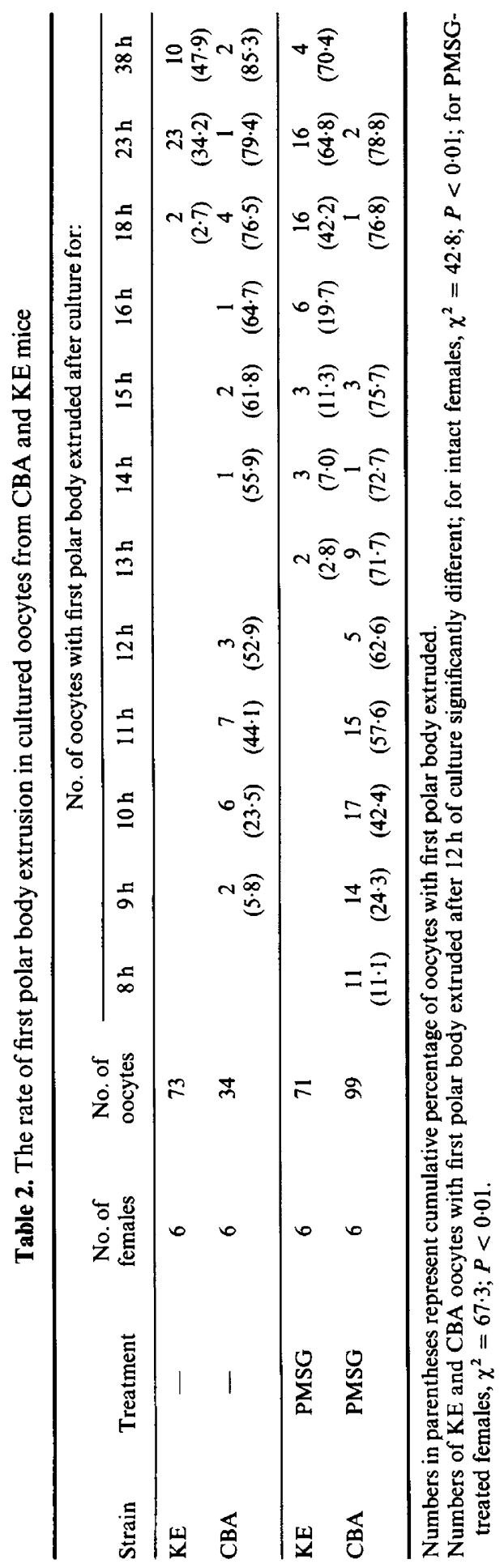


Oocytes from MPSG-primed females of both strains began to extrude the first polar body earlier than oocytes from metoestrous females, but the difference between strains was retained (Table 2).

In both strains GVBD occurred within first $3 \mathrm{~h}$ of culture for the majority $(98 \%)$ of oocytes.

\section{Discussion}

It has been reported that completion of the first meiotic division and first polar body extrusion by mouse oocytes occurs commonly just before ovulation (Edwards \& Gates, 1959; Donahue, 1972). The CBA strain females, used in this study, start to ovulate $12 \mathrm{~h}$ after hCG injection (Wabik-Sliz, 1979) and at this time the majority of oocytes are in metaphase II. However, even by $3 \mathrm{~h}$ before this $79 \%$ of oocytes possess a first polar body. Therefore, the rate of maturation of CBA oocytes is much faster than that observed in other strains of mice.

In contrast, KE oocytes have a long arrest of maturation in metaphase I. Renewal of maturation occurs around the time of ovulation, whether natural or hormonally induced. The metaphase I arrest is therefore not dependent on the use of exogenous gonadotrophins which are known to cause some anomalies, e.g. increased frequency of diploidy in oocytes of NMRI/Han mice (Hansmann \& El-Nahass, 1979; Hansmann et al., 1983) or PMSG-changed pattern of oocyte protein synthesis in the sheep (Moor, Osborn \& Crosby, 1985). In contrast to the above mentioned NMRI/Han mice, the metaphase I arrest of KE oocytes is not permanent because of all of them do complete maturation in few hours after ovulation.

This contrasting behaviour of oocytes from KE and CBA females is genetically determined. In crosses between both strains the rate of oocyte maturation is intermediate in $F_{1}$ hybrid females and segregates in the proportion of $1: 2: 1$ in $\mathrm{F}_{2}$ females, which could indicate that the difference between strains is controlled by one locus (Wabik-Sliz, 1986). However, the physiological factors causing arrest at metaphase $\mathrm{I}$ in $\mathrm{KE}$ oocytes are unknown. It is tempting to suppose that the premature cortical reaction occurring near the time of ovulation in the oocytes of this strain (Wabik-Sliz, 1979) and the breakdown of this arrest could be in some way related.

Control of germinal vesicle breakdown and resumption of meiosis is mediated by somatic components of the follicle (reviewed by Eppig et al., 1983); oocytes released from the follicles undergo spontaneous maturation in vitro. The present results show that the difference between $\mathrm{CBA}$ and $\mathrm{KE}$ oocytes in the rate of their maturation in vivo were also expressed during in-vitro culture. Slow maturation of KE oocytes in the culture is probably due to a transient metaphase I block (as in vivo), because no strain differences in the time of GVBD were noted. However, the process of maturation in vitro was prolonged in both strains and oocytes from females killed at metoestrus (especially in the KE strain) needed more time to extrude their polar bodies than did preovulatory oocytes from females killed after PMSG stimulation. This could reflect the smaller size of antral follicles in the ovaries of unstimulated females, because the ability of the mammalian oocytes to mature in culture and the size of the follicle from which they were released are known to be related (Sorensen \& Wassarman, 1976; Tsuji, Sowa \& Nakano, 1985). However, in both experimental groups, a distinct strain difference in the rate of oocyte maturation was retained. Expression of this difference in the oocytes removed at metoestrus and cultured without contact with somatic components of the follicle indicates that by about 2-3 days before resumption of the meiosis within a given oestrous cycle the rate of maturation of oocytes has already been determined. It has been reported that oocytes isolated from the ovaries of immature mice and cultured in vitro for several days on a fibroblast monolayer resume meiosis at definite times of culture, with a timing strictly corresponding to that in vivo (Canipari, Palombi, Riminucci \& Mangia, 1984). This may indicate that the competence to resumption of meiosis is an intrinsic property of the oocyte. On the other hand, the results of Bartels, Jenderny \& Hansmann (1984) with chimaeric mice seem to suggest that permanent metaphase I arrest of oocytes from mice of the NMRI/Han strain may be affected by somatic cells. 
Therefore, although the rate of maturation of oocytes from metoestrous KE and CBA females seems to be already determined, one cannot exclude that this was influenced by somatic components of the follicle at some earlier stages.

I thank Professor Halina Krzanowska and Dr Barbara Wabik-Sliz for critical reading of the manuscript and helpful advice. This work was supported by the Polish Academy of Sciences within the project $\mathrm{MR}-\mathrm{II} / 9$.

\section{References}

Bartels, I., Jenderny, J. \& Hansmann, I. (1984) Control of meiosis by somatic cells in mice: Inheritance of the meiosis I error "diploidy" and nonexpression in sensitive NMRI/Han oocytes ovulated from chimeras. Cell Differentiation 15, 189-194.

Braden, A.W.H. (1957) The relationship between the diurnal light cycle and the time of ovulation in mice. J. exp. Biol. 34, 177-188.

Canipari, R., Palombi, F., Riminucci, M. \& Mangia, F. (1984) Early programming of maturation competence in mouse oogenesis. Devl Biol. 102, 519-524.

Donahue, R.P. (1968) Maturation of the mouse oocyte in vitro. I. Sequence and timing of nuclear progression. J. exp. Zool. 169, 237-250.

Donahue, R.P. (1972) The relationship of oocyte maturation to ovulation in mammals. In Oogenesis, pp. 413-432. Eds J. D. Biggers \& A. W. Schuetz. University Park Press, Baltimore.

Edwards, R.G. (1965) Maturation in vitro of mouse, sheep, cow, pig, rhesus monkey and human ovarian oocytes. Nature, Lond. 208, 349-351.

Edwards, R.G. \& Gates, A.H. (1959) Timing of the stages of the maturation divisions, ovulation, fertilization and the first cleavage of eggs of adult mice treated with gonadotrophins. J. Endocr. 18, 292-304.

Eppig, J.J., Freter, R.R., Ward-Bailey, P.F. \& Schultz, R.M. (1983) Inhibition of oocyte maturation in the mouse: participation of cAMP, steroid hormones, and a putative maturation-inhibitory factor. Devl Biol. 100, 39-49.

Fulton, B.P. \& Whittingham, D.G. (1978) Activation of mammalian oocytes by intracellular injection of calcium. Nature, Lond. 273, 149-151.

Gilula, N.B., Epstein, M.L. \& Beers, W.H. (1978) Cell-to-cell communication and ovulation: a study of the cumulus-oocyte complex. J. Cell Biol. 78, 58-75.

Hansmann, I. \& El-Nahass, E. (1979) Incidence of nondisjunction in mouse oocytes. Cytogenet. Cell Genet. 24, 115-121.

Hansmann, I., Jenderny, J. \& Probeck, H.D. (1983) Low doses of X-rays decrease the risk of diploidy in mouse oocytes. Mutation Res. 109, 99-110.

Kaleta, E. (1977) Influence of genetic factors on the fertilization of mouse ova in vitro. J. Reprod. Fert. 51, 375-381.
Kaleta, E. \& Polak, Z. (1978) Solubility properties of the zona pellucida of mouse oocytes from inbred strains differing in the number of cortical granules. Zwiertzeta Laboratoryjne 15, 53-61.

Krzanowska, H. (1970) Relation between fertilization rate and penetration of eggs by supplementary spermatozoa in different mouse strains and crosses. J. Reprod. Fert. 22, 199-204.

Krzanowska, H. (1972) Rapidity of removal in vitro of the cumulus oophorus and the zona pellucida in different strains of mice. J. Reprod. Fert. 31, 7-14.

Krzanowska H. \& Lorenc, E. (1983) Influence of egg investments on in-vitro penetration of mouse eggs by misshapen spermatozoa. J. Reprod. Fert. 68, 57-62.

Krzanowska, H., Lorenc, E., Koncewicz, A. \& Lipina, B. (1984) The rate of maturation and fertilizability of oocytes in $\mathrm{KE}$ and $\mathrm{CBA} / \mathrm{Kw}$ female mice with induced superovulation. Zwierzeta Laboratoryjne 21, 3-13.

Moor, R.M., Osborn, J.C. \& Crosby, I.M. (1985) Gonadotrophin-induced abnormalities in sheep oocytes after superovulation. J. Reprod. Fert. 74, $167-172$.

Snedecor, G.W. (1955) Statistical Methods. Iowa State University Press. Ames.

Sorensen, R.A. \& Wassarman, P.M. (1976) Relationship between growth and meiotic maturation of the mouse oocyte. Devl Biol. 50, 531-536.

Tarkowski, A.K. (1966) An air-drying method for chromosome preparations from mouse eggs. Cytogenetics $\mathbf{5}$, $394-400$.

Tsuji, K., Sowa, M. \& Nakano, R. (1985) Relationship between human oocyte maturation and different follicular sizes. Biol. Reprod. 32, 413417.

Wabik-Sliz, B. (1979) Number of cortical granules in mouse oocytes from inbred strains differing in efficiency of fertilization. Biol. Reprod. 21, 89-97.

Wabik-S̈liz, B. (1986) The comparison of some properties of oocytes segregating in $\mathrm{F}_{2}$ hybrids between $\mathrm{KE}$ and $\mathrm{CBA} / \mathrm{Kw}$ inbred strains in mice. Gamete Res. (in press). 